\title{
Turkic poetic heritage as symbol and spectacle of identity: observations on Turkmenistan's Year of Magtymguly celebrations
}

\author{
Paul Michael Taylor* \\ Department of Anthropology, Smithsonian Institution, Washington, DC, USA
}

(Received 9 November 2015; accepted 17 April 2016)

\begin{abstract}
This paper presents one case study of state-sponsored cultural activities that occurred throughout 2014, Turkmenistan's Year of Magtymguly, the 290th anniversary of this Turkmen poet's birth. Such activities constitute examples of public culture; they can organize representations of a society's past and present to reaffirm for participants the values and power structure of their society and revalidate its philosophical underpinnings. After examining this Turkic poet's iconicity, this paper compiles 2014's celebratory events from disparate sources, complementing broader general literature on Central Asia's spectacles of public culture and their role in nationbuilding and identity-formation. Rather than merely resulting from any top-down decision specifying required activities nationwide, the year's events involved numerous synergies as artists, museum and theater administrators, composers, and other cultural-sector workers benefited by responding to the potential of aligning their work with a theme as broad, as widely appreciated, and as eligible for various forms of support as this one. In addition, Turkmenistan's strong central leadership benefited from this widely shared and highly visible celebration, especially emphasizing one element within Magtymguly's eighteenth-century vision, an end to his people's tribal conflicts within a unified Turkmenistan under one leader.
\end{abstract}

Keywords: Turkmenistan; spectacle; public culture; ethnic identity; national identity; Turkic poetry

\section{Introduction}

This paper attempts to interpret observations, admittedly including many made first-hand by the author as participant, regarding the highly coordinated series of cultural activities that took place in Turkmenistan in 2014, designated the Year of Magtymguly by the International Organization of Turkic Culture (TURKSOY) (Gadimova 2014) and enthusiastically celebrated through many state-sponsored events in Turkmenistan. Looking back at 2014 in his New Year's address of 1 January 2015, Turkmenistan's President Gurbanguly Berdimuhamedov concluded that the "declaration of 2014 as the Year of Magtymguly at the international level strengthened the pride of the Turkmen people and their national values and spiritual and cultural heritage" (State News Agency, 2015). Such coordinated celebratory activities, on a large scale, have the characteristics of rituals of public culture, organizing representations of a society's past, present, and future in ways that reaffirm its values

\footnotetext{
*Email: TaylorP@si.edu
}

\footnotetext{
This work was authored as part of the Contributor's official duties as an Employee of the United States Government and is therefore a work of the United States Government. In accordance with 17 USC. 105, no copyright protection is available for such works under US Law.

This is an Open Access article distributed under the terms of the Creative Commons Attribution License (http://creativecommons. org/licenses/by/4.0/), which permits unrestricted use, distribution, and reproduction in any medium, provided the original work is properly cited.
} 
and power structure, and in this case also "sacralize" or make especially valuable its fundamental philosophical underpinnings.

Many authors have noted the importance within Turkmenistan's political context of promoting national identity as a key agenda for the state government (Akbarzadeh 1999; Denison 2009; Polese and Horák 2015), as elsewhere in Central Asia (Adams 2004; Isaacs and Polese 2015). In addition, nation-building and state "spectacles" have been the subjects of multiple journal volumes with regional perspectives. The journal EuropeAsia Studies produced a special issue (61 (7), 2009) on Politics of the Spectacular: Symbolism and Power in Central Asia and Nationalities Papers also recently produced a special issue (43 (3), 2015) titled "Imagined" vs "Real" Nation-Building: Language and Identity Policies between Theory and Practice in Central Asia.

By contrast, in a way that is hopefully complementary to broader or regional studies, I present here a detailed examination of the range and kinds of state-sponsored celebrations carried out during a specific period, dedicated to one specific theme (or historical personage), the eighteenth-century Turkmen poet Magtymguly Pyragy, and suggest how and why that theme (and the modes of celebration selected) was chosen and coordinated in 2014. This requires examining how Magtymguly Pyragy had previously become such a highly iconic and unifying national figure. The core of this paper thus consists of its detailed enumeration of the main commemorative activities of Turkmenistan's Year of Magtymguly, preceded by a brief discussion of why this eighteenth-century poet has such iconic value for the Turkmen people, how his memory and his work have been invoked in different historic contexts to the present, and how this commemorative year's events were organized and coordinated.

Information about one year's celebrations can form a case study for understanding Turkmenistan's state-sponsored thematic years. This is only one year within a series of possibly very differently organized thematic annual celebrations, each worthy of more detailed study. For example, 2015 was named Turkmenistan's Year of Peace and Neutrality, with celebrations marking the twentieth anniversary of Turkmenistan's United Nations-recognized policy of "Permanent Neutrality." Similarly, the international organization TURKSOY had dedicated 2012 to the Azerbaijani playwright Mirza Fatali Akhundzade and 2013 to the Kazakh composer Mukan Tolebayev before naming 2014 the Year of Magtymguly - such annual selections of a Turkic cultural figure having the goal of "popularizing the culture of the Turkic world," as stated by the organization in announcing the Year of Magtymguly (Gadimova 2014).

Among the activities supported directly or indirectly by Turkmenistan's government was the translation of Magtymguly's poetry into more than 22 languages (the author of this paper serving as the editor for the English-language translation, which included an introduction by Berdimuhamedov, see Taylor 2014a) ${ }^{1}$ and two international conferences that included impressive displays of publications issued about Magtymguly in 2014. Following closely after the two-volume annotated compilation of Magtymguly's poetry published by the Institute of Manuscripts in 2013 (Magtymguly 2013), the foreign-language translations of Magtymguly's poetry were released in the course of the year, along with numerous other books. In a special volume celebrating the appearance of so many translations, Turkmenistan's state publishing house produced a large $(32 \times 25 \mathrm{~cm})$, lavishly designed and color-illustrated volume displaying a few selected poems by Magtymguly as translated in many of these new publications, including Turkmen, English, Russian, Arabic, Turkish, Azerbaijani, Uzbek, Kazakh, Chinese, Farsi, Spanish, Korean, Ukrainian, Belarusian, Latvian, Romanian, Kyrgyz, Tajik, Estonian, Tatar, and Armenian (Magtymguly 2014$){ }^{2}$ From the same state press came a pocket-sized $(11 \times 7.5 \mathrm{~cm})$, portable 
Turkmen-language book of Magtymguly's aphorisms, with an introduction by the president (Kön̆ül Nagyşlary 2014). Some other notable books appearing in this year included a scholarly survey of Magtymguly manuscripts (Ashirov 2014) and a detailed publication from Turkmenistan's National Conservatory of Music about traditional bagshy songs of Magtymguly's poetry, set to musical notation (Türkmen Milli Konserwatoriýasy 2014).

The Institute of Manuscripts, within the Academy of Sciences, produced the 2013 "standard" compilation of Magtymguly's poems (see Nuriev 2014) on which translations into at least 22 languages were based. Foreign embassies in Turkmenistan and foreign companies operating there were encouraged to have these poems translated into the national languages of their own countries. Many of these translations, including the Japanese, represented the first time the poet had been translated into that language. In other cases (including English), most poems were translated for the first time, while a few others were given new translations. Many of the translators were also participants in the May 2014 international scientific conference, as was the case with Masahiro Oku, who completed his Japanese-language translation as a student at the Tokyo University of Foreign Studies (Tokyo University of Foreign Studies 2014).

It is best to refer to these translated poems themselves (e.g. in English, Taylor 2014a) for a more direct understanding of Magtymguly Pyragy and his original thought and philosophy. In what follows, by contrast, we concern ourselves with contemporary memory and use of Magtymguly Pyragy as a powerful symbol of Turkmenistan's national identity, as it has been publicly celebrated.

\section{Remembering the eighteenth-century poet Magtymguly Pyragy}

Magtymguly has undoubtedly been a major figure in the spiritual and artistic world of the Turkmen for the last two centuries. He is believed to come from the village of Gerkez along the Etrek river ${ }^{3}$ (now at the border of Iran and Turkmenistan). His father, Dovletmammet Azadi, was also a poet of considerable renown among the Turkmen who continues to be studied today in Turkmenistan (State News Agency of Turkmenistan 2012). The poetry of Magtymguly frequently includes calls for the unity of the Turkmen tribes, along with exhortations to live a virtuous life, which have surely helped him become a renowned spiritual and philosophical leader for the Turkmen people. As Azemoun points out, "Many of his verses have themselves turned into proverbs, which sometimes makes it difficult to distinguish real proverbs from Makhtumkuli's inventions" $(1995,14)$. His poetry has long been a staple of traditional Turkmen bagshy singers (Taylor et al. 2013, 61-63).

The birth and death dates of Magtymguly are regularly listed (within Library of Congress records, for example) as "approximately 1733-approximately 1782"4 - which have never been independently verified and have no clear origin. In the absence of any primary sources of evidence, scholars typically cite the writings of the Hungarian traveler and Turkologist Arminius Vámbéry. In 1863 he recorded that "the national poet, Makhdumkuli, whom they half deify [... and who is] regarded as a sort of saint, was a Turkoman of the Göklen tribe; he died about 80 years ago" (Vámbéry 1865, 368). Vámbéry did not, however, provide Magtymguly's birth date and it is unclear how the year 1733 came to be widely accepted. If this was local knowledge among his descendants, it is surprising we find no such attribution amid Turkmen scholars, whose twentieth century studies often provide other dates. For example, Gurgenli Ahundov (Turkmen, Gürgenli Ahundow) stated Magtymguly's year of birth to be 1731 in a 1940 publication of Magtymguly's poems, only to be contradicted a year later by Ruhy Aliyev (Turkmen, Ruhy Alyýew) in a subsequent anthology of Magtymguly's poems, who reasserted the 1733 date (Ashirov 2013, 380). 
At any rate, it seems in the latter half of twentieth century there was already doubt concerning the accuracy of those commonly cited birth and death dates, in locally published essays written by Turkmen scholars mentioned by Ashirov (2013). Ashirov, the head of the Institute of Manuscripts, argued for a revision of the previously established approximate dates of 1733 and 1783 that ultimately provided the justification for celebrating 2014 as the 290th anniversary of Magtymguly's birth. Ashirov's argument, which refers to the "hypothesis" of an earlier birth date in locally published essays by Turkmen scholars of the 1960s and 1970 s, is worth quoting in full (translating here from the original Turkmen ${ }^{5}$ ):

The hypothesis of these scholars is well-grounded. For example, Magtymguly in his poem For Chovdur Khan wrote that "Chovdur khan went to Ahmet shah to inquire about his state." Based on the historical facts, the last time Ahmet shah went to Mashad was in 1769-1770. Then he died in 1772. If we suggest that Magtymguly was born in 1733, then in 1770 he was at the age of 36-37. But that contradicts the life data of Chovdur khan who went to see Ahmet shah, because Magtymguly concludes his poem devoted to the death of Chovdur khan with these words:

Magtymguly, my peregrine bird flew away,

My patron, my dear friend, my brother,

My gray-haired head cannot comprehend this,

It is surrounded by a haze, Chovdur khan.

If the writer wrote his poem when he already had his hair gray, i.e. when he was already past his middle age, he should had been at least 45 years old then. His verse "My gray-haired head cannot comprehend this" can be a good detail to base this prediction. This and other similar evidences provide us with enough grounds to suggest that Magtymguly was probably born in 1724. (Ashirov 2013, 3)

Ashirov provides no details of these other "similar evidences," and it is unclear how such a specific year as 1724 was selected, although admittedly the reader is also left with the impression that the traditionally used dates of 1733 and 1782 are themselves quite suspect and arbitrary. Undoubtedly Ashirov's citations of Magtymguly's poems in which Magtymguly describes the poet (himself) as of advanced age do clearly indicate that the poet likely lived long past the age of 49, which those 1733-1782 dates would have implied. In addition there are some calendrical references or references to historic events that imply he possibly lived until at least 1806 . In any case, Ashirov posits Magtymguly's birth and death dates as 1724-1807 - a major revision. Apparently the first public presentation and first published reference to this newly proposed 1724 birth date occurred in the paper presented by Ashirov at the 11 October 2012 "Turkmenistan-Korea Joint Conference" held at Korea University (Seoul), having the theme "Central Asia, Korea, and the Silk Road as a Cross-Cultural Network" (Ashirov 2012). ${ }^{6}$

My purpose here is not to dwell on any controversy regarding the details of revising these dates - which are in any case estimates - but rather to point out that the publication and acceptance of this revision, including by the president of Turkmenistan, made possible the nationwide celebration in 2014 of the 290th anniversary of Magtymguly Pyragy's birth.

In April 2013, during preparations for Turkmenistan Culture Days in Washington, DC, the Ministry of Culture informed those involved of the importance of upcoming Magtymguly Year celebrations; in fact the title of our book and exhibition surveying arts of Turkmenistan became Turkmenistan: Arts from the Land of Magtymguly (Taylor et al. 2013). As the authors were choosing a title for this bilingual publication (English and Turkmen), the Turkmen specialists with whom the authors consulted agreed that no other poet's name 
could substitute for Magtymguly's in reference to Turkmenistan as a whole, thus the reference in the subtitle to "Land of Magtymguly."

That book (Taylor et al. 2013; cf. also Taylor et al. 2011) looks at many examples of this eighteenth century Sufi poet's influence on visual arts and music, including a Turkmen gobelin (or pictorial tapestry) from the Soviet period that may suffice here to illustrate visually the role Magtymguly played even prior to independence. ${ }^{7}$ The flat-weave, wool and cotton gobelin with the title Constellation, shown in Figure 1, is in the collection of the Museum of Fine Arts in Ashgabat. Woven between 1982 and 1985 by Turkmen artist Vera Gylliyeva, it depicts seven Turkmen poets standing around the tree of knowledge, a symbol of Turkmen folk wisdom (Hojaguliyev 2005, 9-10).

Magtymguly Pyragy stands at the right of the base of the tree, apparently reciting poetry. At the top of the gobelin and along the tree is a poem written in Cyrillic script that has been stylized to appear Arabic, the script used for the Turkmen language at the time when Magtymguly originally wrote his poems. The two lines shown can be translated as: "When souls, hearts, and minds of tribes are united/When Turkmen gather around one table to share a meal." " In fact, however, only these two lines summarize the four-line stanza of the well-known original poem, ${ }^{9}$ which presented

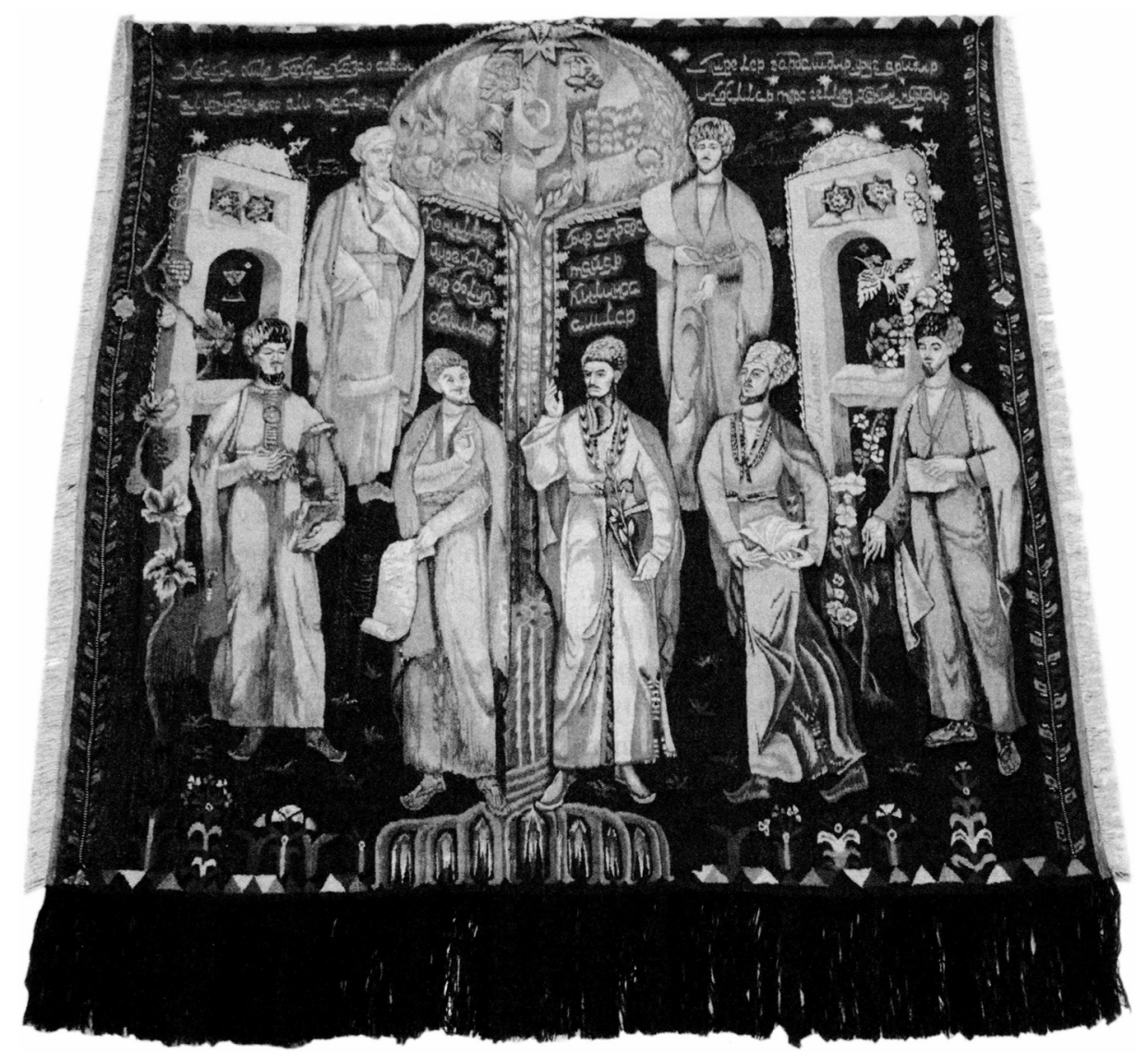

Figure 1. Constellation (Ýedigen). Vera Gylliyeva (1938-). Woven 1982-1985. Wool and cotton, gobelin flat-weaving. $440 \times 365 \mathrm{~cm}$. Courtesy of the Fine Arts Museum of Turkmenistan. Registry number: AHS-938 KEK-9369. 
Magtymguly's dream of a powerful, unified Turkmenistan formed from a union of the Turkmen tribes:

When souls, hearts, and minds of tribes are united/Their troops when gathered will melt stones and ground on their way;/When Turkmen gather around one table to share a meal,/The destiny of Turkmen will rise high.

As if to reinforce the unity of the tribes, the artist's "constellation" of poets depicted here includes seven poets from various Turkmen tribes and localities, ${ }^{10}$ brought together here in an image of unity, within a tapestry filled with motifs like stars, flowers, and birds that are found on carpets or other Turkmen traditional textiles and craftworks.

While it is clear that admiration for Magtymguly developed prior to the arrival of the Soviets, that admiration also ensured his suitability for Soviet purposes. By the time the Turkmen Soviet Socialist Republic was established in 1925 (Abazov 2005; Curtis 1996) there had already been several significant art movements in response to the Bolshevik Revolution of 1917. Beginning with Stalin's cultural policies of the 1930s, socialist realist themes were encouraged in the visual and performing arts of the Soviet Republics for decades. Taylor et al. $(2013,145)$ note that historical figures including Magtymguly "were invoked in order to represent Turkmen ethnic histories within the expected Soviet formats" (Figure 2).

Sultanova $(2011,13)$ has argued that in republics where Soviets promoted modified forms of traditional arts for purposes of nation-building, traditional music was relatively safe from state censorship and could be used to convey the party's message, especially when new words were simply sung to traditional melodies. However, this contrasts markedly with the situation of Magtymguly's poems, all of which could be sung by traditional bagshy singers, during his lifetime and continuing to the present. Instead, a different kind of transformation of Magtymguly's original poetic texts took place, both in the Soviet and post-independence periods. Turkmen musicians created new, very modern compositions using Magtymguly's original poetic texts (Taylor et al. 2013, 63). The works of the contemporary Turkmen composer Nury Halmammedov provide good examples, for both piano and orchestra (Çerkezowa 2013; Gurbanowa 2014; Türkmen döwlet neşirýat gullugy 2012).

Many such artworks and performance forms pre-dating Turkmenistan's independence indicate Magtymguly's role as a symbol and heroic figure for the unification of Turkmenistan, offering in 2014 the promise that celebrating his birth anniversary would be a meaningful event around which to organize "spectacles" in the technical or ethnographic sense, as rituals of public culture. What is certain, and will be demonstrated in the following description of 2014 's celebratory activities, is that the occasion provided the government of Turkmenistan with a convenient and potent symbol of unity around which to mobilize the Turkmen populace. The Year of Magtymguly might be considered a microcosm of political and cultural processes in Turkmenistan today, as they relate to the formation and maintenance of Turkmenistan's strong national identity. It also represented for many people at all levels of society the mobilization of deeply appreciated and valued Turkmen symbols and images of a shared past.

\section{Celebrating the Year of Magtymguly}

On 31 January 2014, the State News Agency of Turkmenistan announced that Berdimuhamedov held an "enlarged meeting" with the Cabinet of Ministers, provincial governors, provincial deputies of culture, and heads of mass media organizations and research institutes to discuss plans for the celebration of the 290th anniversary of Magtymguly. 


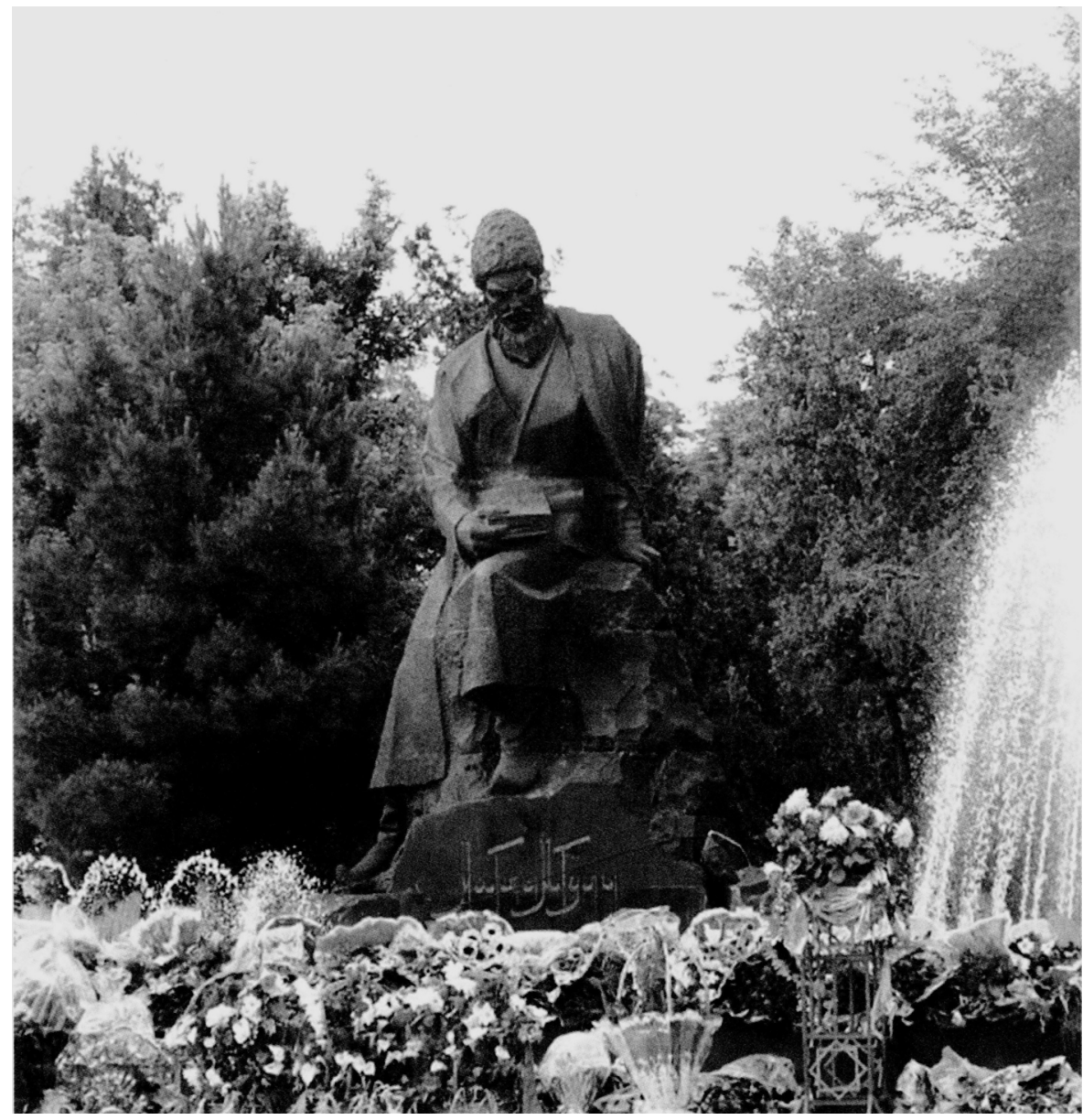

Figure 2. Statue of Magtymguly, with floral decorations placed for the "Days of Magtymguly Poetry" celebrations (May 2013) (from Taylor 2014a, 5). Sculptors: V.N. Vysotin and V.G. Kutumov; design by V.V. Popov. Statue erected in May 1971 on Magtymguly Shayoly Street in Ashgabat, Turkmenistan. Basalt. Inscription on base of statue (Turkmen in Cyrillic script) reads "Magtymguly;" Cyrillic letters have been modified to appear similar to Turkmen written in Arabic script of the kind Magtymguly would have used.

The most visible events scheduled for the jubilee in 2014 were to be held in May to coincide with the 18 May official holiday in celebration of Magtymguly's poetry (Day of Revival, Unity and Magtymguly's Poetry), and the day in 1992 that the country's constitution had been signed. The result is a confluence of celebrations and headlines that, though quite logical in Turkmen, may seem anomalous translated into English, such as "Turkmenistan Celebrates the Constitution Day and Day of Revival, Unity, and Magtymguly's Poetry" (State News Agency of Turkmenistan 2013). Collectively this holiday is, therefore, one of the more important events of patriotism and nation-building within the Turkmen calendar and emphasizes the importance ascribed to Magtymguly as a political symbol of unity in twenty-first century Turkmenistan. 
Turkmenistan's previous president, Saparmurat Niyazov, published his Rukhnama in 2001, a year after the establishment of the Day of Revival, Unity, and Magtymguly's Poetry, in which he refers to Magtymguly as "our Father Magtymguly" among the Turkmen (Turkmenbashi 2001, 153). Such explicit connections between the constitution, Magtymguly's paternal guidance, and Turkmen unity seem to represent the present nation of Turkmenistan as the historical fulfillment of Magtymguly's centuries-old dream of the unification of Turkmen tribes under a single leader.

The celebrations and official ceremonies on this day typically include state officials laying wreaths at the Monument of the Constitution and the Monument to Magtymguly Pyragy in Ashgabat, followed by well-attended festivals featuring highly choreographed music and dance performances inspired by the songs and poetry of Magtymguly. For the 290th anniversary these celebrations were to be expanded upon considerably, and, as made clear by the TURKSOY declaration and other activities (including those in which this author played a role) brought onto an international stage.

A special seal for the 2014 Year of Magtymguly celebration was developed (Figure 3), appearing on numerous 2014 government publications, at placards prominently displayed for conferences or exhibitions, and on banners widely seen along the streets of Ashgabat

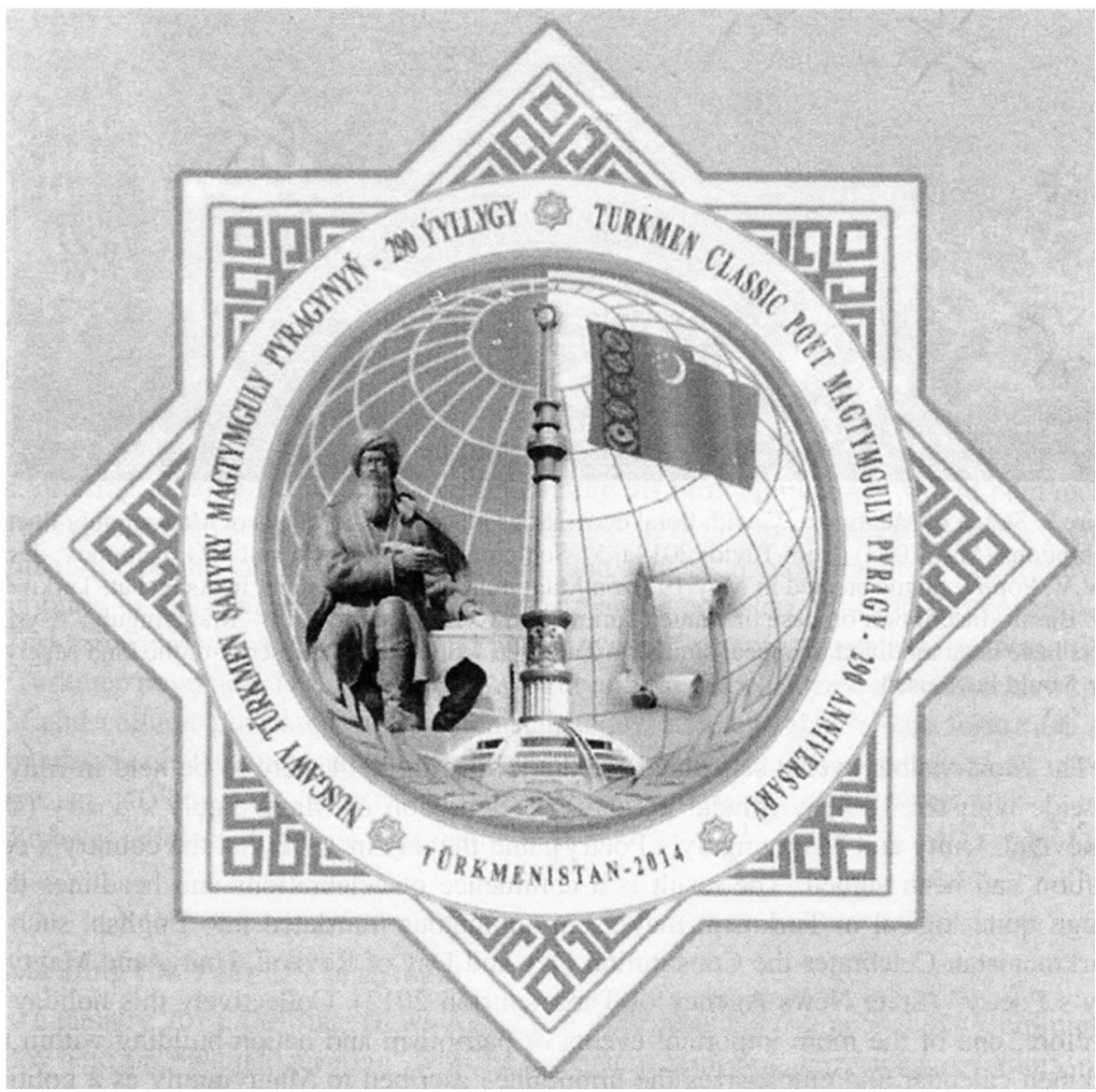

Figure 3. Year of Magtymguly seal of the government of Turkmenistan. 
and other cities for much of the year. The seal's global backdrop for the Turkmen images (including the statue of Magtymguly and the image of his written poem) seems to reflect the desire to see this important Turkmen cultural icon recognized on the broader international stage.

Along with a collective international effort to translate the poetry of Magtymguly into many of the languages of the world, the Turkmen State Publishing Service produced several new publications in Turkmen on the life and philosophy of Magtymguly to coincide with the jubilee (State News Agency of Turkmenistan 2014b). These works included titles such as Magtymguly and Eastern Literature, Legends about Magtymguly Fraghi, Magtymguly Fraghi: A Source of Inspiration, Studies of Magtymguly's Manuscripts, and The Mirror of the Soul, which was a collection of scholarly articles about the poet (New Europe 2014).

The special attention given to Magtymguly in this year extended beyond the realm of new literature. Museums brought out their artworks relating to the poet for prominent display. Artistic and cultural works in Turkmenistan, largely supported by the state, often draw from nationalistic or state-sponsored themes; so in this year many artists created works inspired by the life and philosophy of Magtymguly. Though apparently not the subject of published studies, there seems to have been substantial activity in the sphere of visual arts, as a proliferation of new paintings featuring Magtymguly were on display during the international scientific conference described below, though these were without information and remain uninvestigated. ${ }^{11}$

As noted below in the description of the May academic conference, a gala concert was held during that international conference held at the Palace of Meetings (Maslahat Kosgi), with folk groups, dance ensembles, and pop singers performing songs based on Magtymguly's poems. The opera Magtymguly Fraghi, which had been written specifically for the Year of Magtymguly celebrations and had premiered in 2013, was performed again at the Turkmen National Music and Drama Theater (also, incidentally, named after Magtymguly) by some of Turkmenistan's preeminent performers. These performers were drawn from the Magtymguly National Music and Drama Theater, the State Choir, and faculty and students of the National Conservatory of Turkmenistan. There were also "musical evenings" dedicated to Magtymguly held in all regions of Turkmenistan (Nuriev 2014). The "Turkmenfilm" Association, Oguzkhan, also produced a historical drama (in late 2013 for 2014 broadcast) titled Magtymguly, which "recreates a multifaceted image of the poet-patriot" (Nuriev 2014).

During this year of celebrations, the image of Magtymguly also seemed ubiquitous throughout the city of Ashgabat on billboards and signage promoting the Year of Magtymguly (Figure 4(a) and 4(b)). Along major thoroughfares, rows of streetlight posts held banners announcing the anniversary, often with lines from his poetry and an image of Ashgabat's locally well-known statue of Magtymguly. The statue, of Magtymguly wearing a turban and seated at a desk with a quill and book, had been constructed in 2001 in a way that contrasted with the earlier official image of Magtymguly in the traditional Turkmen wool cap known as a telpek. Similarly, during the major Year of Magtymguly events, Turkmen state television broadcasts featured long news segments about celebratory events such as the academic conference in May, while Turkmenistan's state newspapers, such as "Neutral Turkmenistan," published extensive reports as well.

As mentioned above, one important, highly planned and coordinated event within this international component of the Year of Magtymguly celebrations was the "international scientific conference" held from 14 to 16 May with a title - "Magtymguly Pyragy and Universal Cultural Values" - that echoed the progressive Soviet rhetoric of the past. Attended by hundreds of scholars, primarily from Turkmenistan and other post-Soviet countries but 

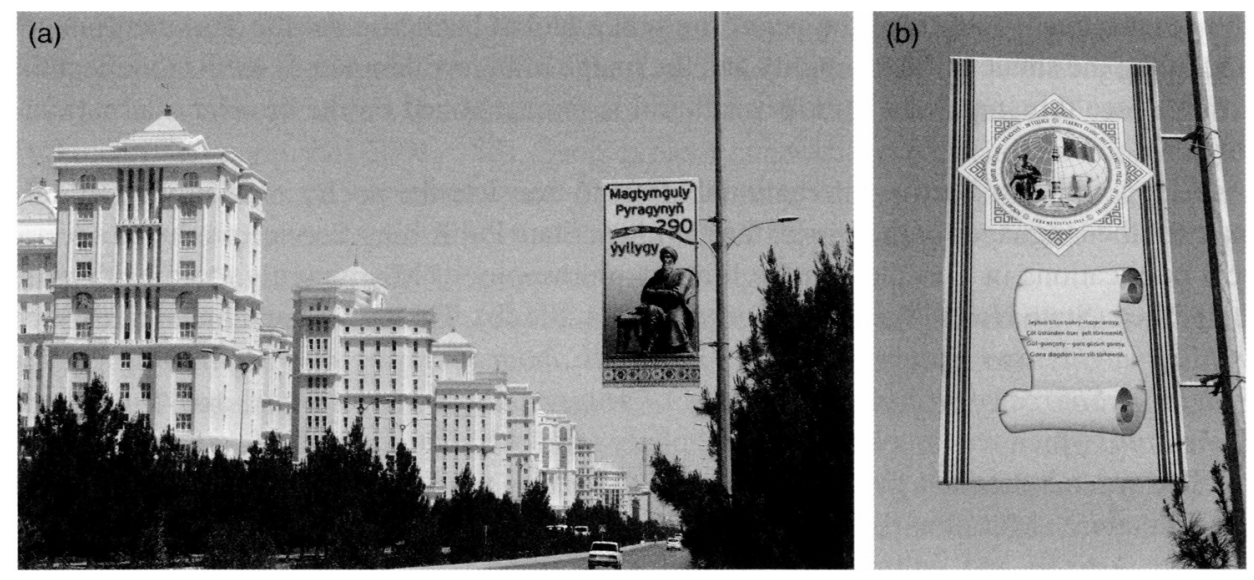

Figure 4 (a) and (b). Street banners in Ashgabat, Turkmenistan (May 2014) commemorating the 290th anniversary of the poet. Many of these featured the official seal created for the anniversary, or the statue of Magtymguly in the Independence Monument complex.

also many representatives from Turkey, the Middle East, East Asia, Europe, Africa, South America, and the United States, this major conference was organized by the Academy of Sciences of Turkmenistan and the Ministry of Culture. Amid great hospitality and grand tours, award ceremonies, performances, and banquets, there was a celebratory atmosphere with a high level of official recognition. Academic papers were delivered on the last day of the conference (Türkmenistanyň Ylymlar Akademiýasy 2014).

After a day of sightseeing at the State Museum of the State Culture Center of Turkmenistan, Ylham Park (or "Inspiration" Park), the second day of the conference featured an opening event with an award ceremony presided over by President Berdimuhamedov at the Ruhiyet Palace. The Magtymguly International Prize was awarded to several dignitaries in attendance, including Director-General of UNESCO Irina Bokova. Following this ceremony at Ruhiyet Palace, conference participants were taken to the Magtymguly Turkmen State University, where other foreigners as well as citizens of Turkmenistan were awarded the Magtymguly Medal, established in 2014 to recognize various kinds of public service.

Other main events included a concert at the Maslahat Palace and opera performance at the Magtymguly National Music and Drama Theater. Denison (2009) regards these highly choreographed concerts or dance routines in Turkmenistan as demonstrating a "rigid conformity" or symbolizing power and coercion imposed on Turkmen people. Certainly from a foreign perspective, the norm in state-sponsored public performances may seem to be a lack of individualized self-expression, making large scale and spectacularly choreographed performances particularly memorable, albeit with little uniquely individual artistry. Yet these Turkmen performances are therefore quite different from those of traditional singers (bagshy) in more intimate settings. Many public concerts during the May conference consisted (as is common in Turkmenistan) of amplified, recorded pop melodies while performers lip-synched some of their vocal performances (Denison 2009, 1182 refers to this as "miming") and carried out choreographed dance routines. This seems to reflect Turkmen listeners' seemingly widespread acceptance of concerts playing recorded music while performers pretend to play instruments or sing on stage, using instruments without microphones and lip-synching, as if to reduce, insofar as possible, any chance of imperfection 
at such a public venue. Thus the Turkmen "aesthetic" norm applied to highly public live performances may simply compare to the norms American audiences apply when watching a music video or listening to a $\mathrm{CD}$, fully expecting that what they see and hear has been modified from any original live event. However we choose to interpret Turkmen performances of this nature, they were likely repeated numerous times for other occasions celebrating the Year of Magtymguly as well. Foreigners are unaccustomed to this method of performance, and might be misinterpreting it; and though Turkmen professional performers also may not prefer this mode, Turkmen audiences do seem to respond enthusiastically, judging admiringly the degree to which performers align movements with the broadcast recordings. All the conference's events, including the concerts, were widely covered by Turkmen press.

On the final day of this May conference, three hours were set aside for the delivery of brief versions of all 316 papers, at many simultaneous sessions at different venues in Ashgabat. Languages of delivery (and of simultaneous translations) were Turkmen, Russian, and English. The papers were grouped together based on the general themes of the conference, into the following four topics: (1) The Prosperous Epoch of the Powerful State and Magtymguly Pyragy; (2) Magtymguly and His Epoch; (3) Magtymguly's Poetry World; (4) Magtymguly and World Literature; and (5) Magtymguly and Turkic Languages.

On 12-15 December 2014, serving as a closing ceremony for the Year of Magtymguly, another international conference was held in Ashgabat, on the theme "Magtymguly is the desire of the souls," hosted by the Academy of Sciences and the Ministry of Culture. (No book of abstracts or proceedings for that conference was published.) Again the conference had associated exhibitions of fine arts, sculpture, jewelry, and crafts dedicated to Magtymguly, as well as tours and concerts arranged for participants (including this author).

\section{Year of Magtymguly celebrations abroad}

Several other projects and events beyond the borders of Turkmenistan recognized the legacy of Magtymguly, primarily presentations, book launches, poetry evenings, and similar commemorative events, mostly in the former Soviet Union but also in other countries. As noted above, the TURKSOY, which represents the cultural interests of Azerbaijan, Kazakhstan, Kyrgyzstan, Turkey, Turkmenistan, and Uzbekistan, declared 2014 the Year of Magtymguly (Gadimova 2014).

In April 2014, a delegation from Turkmenistan visited the neighboring Stavropol and Astrakhan regions in the southern tip of Russia near the border with Georgia, historically home to a small Turkmen diaspora. Organized by the Consulate of Turkmenistan in Astrakhan in conjunction with the administration of the Blagodarnensk district in Stavropol, festivities in Stavropol included the laying of flowers at a monument to Magtymguly in the village of Edelbai, a concert, wrestling competitions and horse racing, and a traditional Turkmen toy, or celebration, all attended by heads of the Stavropol districts and local Turkmen. In Astrakhan, a similar concert and exhibition of traditional Turkmen art was held in the village of Funtovo while a flower-laying ceremony was held at the Magtymguly monument in Astrakhan City, followed by a concert at the Astrakhan State Conservatory (Turkmenistan.ru, 20 May 2014). A comparable conference and celebration was held in Yerevan, Armenia, in April at the Yerevan State University, where a delegation of Turkmen scholars and "cultural workers" discussed Magtymguly with scholars from the university. The plenary session of the conference included Aram Simonyan (rector of Yerevan State University), Alexander Safarian (head of the Turkology Department at Yerevan State University), and Annagurban Ashirov (director of the National Institute of 
Manuscripts of Turkmenistan) (Turkmenistan.ru, 7 April 2014). Furthermore, in May 2014 in St. Petersburg the Eastern Department of the St. Petersburg University Library opened the exhibition "The Imperishable Word of Magtymguly," which featured scholarly treatments of the poet's work and a discussion of his contribution to Turkmen literature and language (Iskhanov 2014). Also in April, the Fatih University of Istanbul hosted a conference on "Magtymguly and World Culture," attended by a delegation of scholars from Turkmenistan and complemented by a concert held by Turkmen musicians in the delegation (State News Agency of Turkmenistan 2014c). A similar conference titled "Magtymguly and Turkic Literature" was held in Almaty, Kazakhstan, in early May (Turkmenistan.ru, 3 May 2014).

Book launches were held in many countries for the new translations of Magtymguly, often complemented by performances of Turkmen music and dance. Events of this nature occurred at several cities in 2014, including Tokyo (The Japan Times 2014), Seoul (State News Agency of Turkmenistan 2014a), Granada (Escuela de Estudios Árabes 2015), Kirovograd (Turkmenistan.ru, March 24, 2014), and Berlin (Turkmenistan.ru, 29 May 2014).

Also in May 2014 a delegation of Turkmen visited the purported grave of Magtymguly in the Aktokay settlement of the Golestan province in Iran, which shares a border with Turkmenistan. This annual visit by an official delegation of Turkmen cultural workers had occurred on the eve of the Day of Magtymguly every year since 1999, when a new mausoleum devoted to Magtymguly had opened in Aktokay. It represents one of the Year of Magtymguly activities that actually recurs every year and was not initiated especially for the 290th anniversary (Radio Free Europe, 17 May 2011). Following this visit in 2014, the delegation also stopped in nearby Gerkez on the Turkmen side of the Iran-Turkmenistan border. Magtymguly was born in Gerkez and for the 2014 celebrations many events were planned to commemorate the poet there, including the inauguration of a monument dedicated to him, the laying of a foundation stone for the memorial complex and new museum dedicated to Magtymguly, and a festival that featured performances by poets and writers (Nuriev 2014).

The conferences, book launches, and similar events outside Turkmenistan were often organized in collaboration with local Turkmen embassies as well as the National Institute of Manuscripts and Academy of Sciences of Turkmenistan, and were prominently featured in Turkmenistan's state media. Collectively they very visibly projected an image at home of Turkmenistan's growing significance on the international stage.

\section{Conclusion}

The compilation and summary of information here, about a specific and coordinated yearlong set of activities, has hopefully presented a useful description of a phenomenon of Turkmen public culture that admittedly deserves further study. The memories about and present-day uses of important or heroic historic figures (including literary figures) constitute components of national identity in every country. Within Turkmenistan, the underlying philological and literary study of Magtymguly's poetry itself - both from manuscript sources and from the traditional songs that preserve his verses in oral form - also deserves more study.

This paper set out to complement and add to existing literature about spectacles and public culture by bringing together information for a more detailed case study. Turkmenistan celebrated in 2014 the 290th anniversary of the birth of a great Turkmen poet in ways that are surely unique to that country, sometimes with methods seemingly inherited from 
decades of Soviet influence, but in other ways using highly localized references and symbols. The poet's recently revised birth year, which made these 290th anniversary celebrations possible, was ultimately no less correct (and probably more likely to have been correct) than many other birth years that might have been chosen. Not to be forgotten amid the study of public culture as represented within such state-sponsored celebrations is the important fact that Magtymguly actually is a literary figure worthy of higher world recognition and truly deserving of re-reading and celebrating - though that argument is outside the scope of this paper, which focuses on Magtymguly's iconicity for the Turkmen and how that gets publicly used.

There were many positive results from the fact that individuals within the Academy of Sciences called attention to, and gained high-level acceptance for, their proposed revision of a national hero's birth year, which inspired so many cultural activities. From the compilation above, we see that the missions of many scientific and scholarly organizations, and producers of the arts, surely benefited. New books, musical compilations, opera, films, and other artistic productions all apparently became possible by connecting them in some way to this heavily encouraged theme during this specific period of time. Far from being just a year of activities detailed in a top-down decision requiring activities nationwide, the year saw numerous synergies develop as artists, museum and theater administrators, composers, and cultural-sector workers of many kinds negotiated the potential benefits of aligning their work with a theme as broad, as widely appreciated, and as eligible for various forms of support as this one.

In addition, it is clear that Turkmenistan's strong central leadership benefited from a widely shared and visible national celebration of the fulfillment of one element within Magtymguly's eighteenth century vision, for the poet had indeed dreamed of an end to the region's tribal conflicts within a unified Turkmenistan.

\section{Notes}

1. The English translation of Magtymguly's poetry was generously supported by Chevron, and received no funding from the Turkmenistan government; however this project did have strong Turkmenistan government scholarly support through the Institute of Manuscripts, Turkmenistan Academy of Sciences, whose compilation of Magtymguly's poems was the basis for translation (see Taylor 2014b). That Institute's scholars regularly responded to numerous specific questions about elements of the texts throughout the translation process, giving high priority to assisting all the foreign-language translations that were published in 2014, not only the English translation. For advice and research assistance in the preparation of this article, the author wishes to thank Trevor Merrion.

2. Additional new translations of Magtymguly's poems published in 2014 included Japanese and Urdu.

3. These facts are typically derived from Magtymguly's own poems, for example, "When asked by those who don't know, tell them my poor name,/That I am Gerkez, my motherland is Etrek and my name is Magtymguly" (Taylor 2014a, 19).

4. Library of Congress author record: http://id.loc.gov/authorities/names/n84089651.html.

5. This essay has also been translated into Spanish and published on pages 177-190 as an appendix to Kohrs and Muñoz's (2014) Spanish translation of Magtymguly's poems.

6. Proceedings of this conference are unpaginated, in Korean and English; Ashirov's paper is in English.

7. This example, among many, is taken from Taylor et al. (2013, 203); and cf. Taylor and Merrion (2014, 150-151).

8. Original text in Turkmen (Cyrillic script): “Көңуллер йуреклер бир болуп башлар Бир супрада тайар кылынса ашлар." 
9. See full English translation, Taylor (2014a, 15). A table of poem titles in English and Turkmen (Taylor 2014a, 205-211) links each poem selected for translation to the original Turkmen poem published earlier by Ashirov (2013).

10. The other six poets shown are Dovletmammed Azadi (1700-1760), Gurbandurdy Zelili (1789_ 1844), Mamedveli Kemine (1770-1840), Seyitnazar Seidi (1775-1830), Mollanepes (18101862), and Annaklych Myatyaji (1824-1884).

11. The economics and incentives for this new artistic production, though not yet investigated in detail, would be a worthwhile subject of more detailed research. Artists sometimes display their new works at public events but with no information about the artists' names or contact information, though with time it should be possible to identify the sources and interview contemporary artists on many aspects of their creative work and its relation to state and other forms of sponsorship and inspiration.

\section{References}

"290th Anniversary of Mahtumkuli Fraghi Celebrated in Yerevan.” 2014. Turkmenistan.ru: internetgazeta, April 7. http://www.turkmenistan.ru/en/articles/17660.html.

Abazov, Rafis. 2005. Historical Dictionary of Turkmenistan. Lanham, MD: Scarecrow Press.

Adams, Laura. 2004. "Cultural Elites in Uzbekistan: Ideological Production and the State." In The Transformation of Central Asia: States and Societies from Soviet Rule to Independence, edited by Pauline Jones Luong, 93-119. Ithaca, NY: Cornell University Press.

Akbarzadeh, Shahram. 1999. "National Identity and Political Legitimacy in Turkmenistan." Nationalities Papers 27 (2): 271-290.

Aşyrow, Annakurban [Ashirov, Annagurban]. 2012. "Magtymguly Pyragy." Paper presented at Central Asia, Korea, and the Silk Road as a Cross-cultural Network. 2012 TurkmenistanKorea Joint Conference, Seoul.

Aşyrow, A. (Annakurban) [Ashirov, Annagurban]. 2013. "Magtymguly Pyragy.” In Magtymguly: Eserler ýgyndysy, edited by Pyragy Magtymguly, vol. 2, 377-399. Ashgabat: Ylym.

Aşyrow, A. (Annakurban) [Ashirov, Annagurban]. 2014. Magtymgulyny̌̆ Golżazmalarynyn̆ Derňewi. Ashgabat: Türkmen döwlet neşirýat gullugy.

Azemoun, Yousef. 1995. "Introduction." In Songs from the Steppes of Central Asia: The Collected Poems of Makhtumkuli: Eighteenth Century Poet-hero of Turkmenistan, edited by Yousef Azemoun and Brian W. Aldiss, 4-15. Caversham: Society of Friends of Makhtumkuli.

Çerkezowa, Parahat. 2013. Nury Halmämmedow (20. IV. 1938 4. VIII. 1983). Ashgabat: Ylym.

Curtis, Glenn E., ed. 1996. Turkmenistan: A Country Study. Washington, DC: Library of Congress.

Denison, Michael. 2009. "The Art of the Impossible: Political Symbolism and the Creation of National Identity and Collective Memory in Post-Soviet Turkmenistan." Europe-Asia Studies 61 (7): 1167-1187.

Escuela de Estudios Árabes. 2015. Encuentro con investigadores turkmenos del Instituto Nacional de Manuscritos. Granada: Escuela de Estudios Árabes. http://www.eea.csic.es/index.php?option= com_content\&task=view\&id $=810$.

Gadimova, Nazrin. 2014. “TURKSOY: 2014 Year of Turkmen Poet Pyragy.” Azernews, February 10. http://www.azernews.az/culture/64231.html.

Gurbanowa, Jemile [Gurbanova, Jamilla]. 2014. Nury Halmämmet. Ashgabat: Türkmenistanyň medeniżet ministrligi türkmen milli konserwatoriżasy; Ylym.

Hojaguliyev, K. 2005. "The Founders of Gobelin Art of Turkmenistan.” Unpublished MS. Ashgabat: Saparmurat Turkmenbashi Fine Arts Museum of Turkmenistan.

"International Conference Dedicated to Turkmen Poet Magtymguly Fraghi Held in Kazakhstan." 2014. Turkmenistan.ru: internet-gazeta, May 3. http://www.turkmenistan.ru/en/articles/ 17699.html.

Isaacs, Rico, and Abel Polese. 2015. "Between 'Imagined' and 'Real' Nation-building: Identities and Nationhood in Post-Soviet Central Asia." Nationalities Papers 43 (3): 371-382.

Iskhanov, Anton. 2014. "Istoriia odnoi mechty: molodoi rossiiskii vostokoved ob ustanovlenii pamiatnika Makhtumkuli v Sankt-Peterburge." Infoabad.com, July 15. http://infoabad.com/ obrazovanie-nauka-i-tehnika/-istorija-odnoi-mechty-molodoi-rosiiskii-vostokoved-ob-ustanovlenipamjatnika-mahtumkuli-v-sankt-peterburge.html. 
"Japanese Edition of Turkmen Poet's Work." 2014. The Japan Times, November 25. Accessed October 30, 2015. http://www.japantimes.co.jp/news/2014/11/25/national/japanese-editionturkmen-poets-work/\#.VjPBvq6rQUE>.

Kohrs, Helga, and Alejandro Muñoz, eds. 2014. Magtymguly: poemas. Translated (Spanish) by Helga Kohrs and Alejandro Muñoz. Ashgabat: Institute of Manuscripts.

Kön̆̈̈l Nagyşlary. 2014. Ashgabat: Türkmen döwlet neşirýat gullugy.

Magtymguly, Pyragy. 2013. Magtymguly: eserler żygyndysy. 2 vols. Edited by A. Aşyrow (Annakurban) [Ashirov, Annagurban]. Ashgabat: Ylym.

Magtymguly, Pyragy. 2014. Magtymguly: Goshgular. Ashgabat: Türkmen döwlet neşirýat gullugy.

Nuriev, Ahmetdzhan. 2014. "More than a Poet." Turkmenistan: International Magazine (Turkmenistan: Mezhdunarodnii Zhurnal) 5 (6): 110-111. http://www.turkmenistaninfo.ru/? page_id=6\&type=article\&elem_id=page_6/magazine_191/1635\&lang_id=en.

Polese, Abel, and Slavomír Horák. 2015. "A Tale of Two Presidents: Personality Cult and Symbolic Nation-Building in Turkmenistan." Nationalities Papers 43 (3): 457-478.

State News Agency of Turkmenistan. 2012. "The Creative Work of Azadi - An Integral Part of the National and the World Spiritual Culture." Turkmenistan: The Golden Age, May 12. http:// www.turkmenistan.gov.tm/_eng/?id=803.

State News Agency of Turkmenistan. 2013. "Turkmenistan Celebrates the Constitution Day and Day of Revival, Unity, and Magtymguly's Poetry." Turkmenistan: The Golden Age, May 18. http:// www.turkmenistan.gov.tm/_eng/?id=2289.

State News Agency of Turkmenistan. 2014a. "A Celebration in Honor of Magtymguly - Classic of the World Poetry Is Arranged in Seoul." Turkmenistan: The Golden Age, April 3. http://www. turkmenistan.gov.tm/_eng/?id=3392.

State News Agency of Turkmenistan. 2014b. "An Enlarged Meeting of the Cabinet of Ministers." Turkmenistan: Golden Age, January 31. http://www.turkmenistan.gov.tm/_eng/?id=3179.

State News Agency of Turkmenistan. 2014c. "Poetry of Magtymguly - A Valuable Property of Humankind." Turkmenistan: The Golden Age, April 7. http://turkmenistan.gov.tm/_eng/?id= 3408.

State News Agency of Turkmenistan. 2015. "New Year's Address of President of Turkmenistan Gurbanguly Berdimuhamedov." Turkmenistan: The Golden Age, January 1. http://www. turkmenistan.gov.tm/_eng/?id=4364.

Sultanova, Razia. 2011. From Shamanism to Sufism: Women, Islam and Culture in Central Asia. London: I B. Tauris.

Taylor, Paul Michael, ed. 2014a. Magtymguly: Poems from Turkmenistan. (With an introduction by Gurbanguly Berdimuhamedov, President of Turkmenistan). Washington, DC: Asian Cultural History Program.

Taylor, Paul Michael. 2014b. "Preface to the English Translation of Magtymguly's Poems." In Magtymguly: Poems from Turkmenistan, edited by Paul M. Taylor, 10-12. Washington, DC: Asian Cultural History Program.

Taylor, Paul Michael, and Trevor Merrion. 2014. "Turkmen ‘Gobelin' or Pictorial Tapestries.” Arts of Asia 44 (2): 142-153. [\& author information p. 3].

Taylor, Paul Michael, Trevor Merrion, William Bradford Smith, and Jasper Waugh-Quasebarth. 2013. Turkmenistan: Arts from the Land of Magtymguly. Washington, DC: Asian Cultural History Program, Smithsonian Institution.

Taylor, Paul Michael, Trevor Merrion, Jasper Waugh-Quasebarth, and William Bradford Smith. 2011. Turkmenistan: Ancient Arts Today. Washington, DC: Asian Cultural History Program, Smithsonian Institution.

Tokyo University of Foreign Studies. 2014. "TUFS Student Awarded 'Magtymguly Pyragy Medal Pyragy Medal' on May 16th." October 20. http://www.tufs.ac.jp/english/2014/10/14102201. html.

"A Tribute to Turkmen Poet Magtymguly Fraghi." 2014. New Europe, May 5. http://neurope.eu/ article/tribute-turkmen-poet-magtymguly-fraghi/.

Türkmen döwlet neşirýat gullugy. 2012. Nury Halmämmedow: fortepiano we wokal sazlary. Ashgabat: Türkmen döwlet neşirżat gullugy.

Türkmen Milli Konserwatoriýasy. 2014. Magtymgulynyň Goşgularyna Aýdymlar. Ashgabat: Ylym neşirýaty. 
Türkmenistanyň Ylymlar Akademiýasy. 2014. Magtymguly Pyragy and Universal Human Cultural Values: Abstracts of Reports of the International Scientific Conference, May 14-16, 2014. Ashgabat: Ylym neşirýaty. [Also available in Turkmen and Russian editions].

"Turkmen Pilgrims Return from Iranian Shrine to National Poet." 2011. Radio Free Europe: Radio Liberty, May 17. http://www.rferl.org/content/turkmen_pilgrims_return_iran_shrine_national_ poet_magtymguly_pyragy/24176898.html.

“Turkmen Diaspora of Russia Celebrates Magtymguly's Anniversary.” 2014. Turkmenistan.ru: internet-gazeta, May 20. http://www.turkmenistan.ru/en/articles/17715.html.

Turkmenbashi, Suparmyrat. 2001. Ruhnama. Ashgabat: Türkmen döwlet nesirýat gullugy.

Vámbéry, Arminius. 1865. Travels in Central Asia: Being the Account of a Journey from Teheran across the Turkoman Desert on the Eastern Shore of the Caspian to Khiva, Bokhara, and Samarcand. New York: Harper \& Brothers.

"V Berline proshel vecher poezii Makhtumkuli." 2014. Turkmenistan.ru: internet-gazeta, May 29. http://www.turkmenistan.ru/ru/articles/39773.html. 